\title{
Physicochemical and Microbiological properties of soil in Ahoko: A Suspected Petroleum Bearing Site (SPBS)
}

\author{
Munachimso Odenakachi VICTOR-EKWEBELEM ${ }^{* 1}$, Udeme Joshua Josiah IJAH ${ }^{2}$, Olabisi Peter ABIOYE ${ }^{3}$ \\ and Yahaya Baba ALKALI ${ }^{4}$ \\ 1, 5 Department of Biology/Microbiology/Biotechnology, Alex Ekwueme, Federal University Ndufu-Alike. P.M.B 1010, \\ Abakaliki, Ebonyi State, Nigeria. \\ ${ }^{2,3}$, Department of Microbiology, Federal University of Technology P.M.B.65, Minna, Niger State, Nigeria. \\ ${ }^{4}$ Department of Geology, Federal University of Technology P.M.B.65, Minna, Niger State, Nigeria. \\ "Corresponding author: E-MAIL: preciouselemba@ gmail.com, Tel: +2347068254049
}

DOI: $10.31364 / S C I R J / v 8.15 .2020 . P 0520772$

http://dx.doi.org/10.31364/SCIRJ/v8.i5.2020.P0520772

\begin{abstract}
Microbial surface prospecting is a vital process in the exploration of hydrocarbon suspected site, as a result the aim of this study was to assess the microbial and physicochemical properties of soil in a suspected petroleum bearing site at Ahoko, Kogi State, Nigeria, to ascertain the potent site for exploration using the presence of microbial anomalies. The four identified sites; A, B, C and D were mapped and gridded. Soil samples were collected from each of the sites and analysed for physicochemical properties, culturable heterotrophic aerobic bacteria, total fungi and distribution of specific hydrocarbon oxidizing microbes. Physicochemical properties showed that $\mathrm{pH}$ of the sites were within the range of 5.30 to 7.05 . Site A had the highest total organic carbon $(1.18 \%)$, conductivity $(12.0 \pm 3.50 \mu \mathrm{f} / \mathrm{cm})$, available Phosphorus $(12.06 \pm 0.00 \mathrm{mg} / \mathrm{kg})$, base saturation $(66.03 \pm 0.00 \%)$ and exchangeable acid $(2.28 \pm 0.58 \mathrm{cmol} / \mathrm{kg})$ compared to other sites. The aerobic heterotrophic bacteria in the soil varied with respect to the month of sampling/site at the range of $0.38 \times 10^{6} \mathrm{CFU} / \mathrm{g}$ to $2.88 \times 10^{6} \mathrm{CFU} / \mathrm{g}$. Total number of culturable fungi ranged from $1.27 \times 10^{3} \mathrm{CFU} / \mathrm{g}$ to $11.0 \times 10^{3} \mathrm{CFU} / \mathrm{g}$. Site A had the highest number of methane and ethane oxidizing microbes. Site $\mathrm{C}$ showed the highest number of propane oxidizing microbes of $1.15 \times 10^{2} \mathrm{CFU} / \mathrm{g}$ while $\mathrm{C}$ had the least, $0.04 \times 10^{2} \mathrm{CFU} / \mathrm{g}$. There was little or no growth of butane oxidizing microbes in all the sites. The study revealed the presence of high concentrations of hydrocarbon oxidizing bacteria in Ahoko area of Bida basin. Site A had higher population of ethane oxidizing bacteria than the rest of the sites and therefore, it could be a possible site for hydrocarbon in Bide basin.
\end{abstract}

KEYWORDS: Petroleum, Soil, Ahoko, Total count, Sites, Microbes

\subsection{Introduction}

Bida basin has been reported as one of the suspected petroleum bearing sites in Niger State, Nigeria, this Basin is, located in the North Central Region (Figure 1). According to Ladipo (1998) the Basins' sedimentary fill comprises post-orogenic molasses and thin unfolded marine sediments. The basin is a gently down-warped trough whose origin is closely connected with Santonian orogenic movements in South East Nigeria and the Benue valley. The basin trends perpendicular to the main axis of the Benue Trough and the Niger Delta Basin and is regarded as the North West extension of the Anambra Basin, both of which were major depocentres during the third major transgressive cycle in the Late Cretaceous (Obaje et al., 2011). The areas surrounding Bida and South of Bida towards Pategi, Muregi, Baro, Agbaja, Ahoko, Abaji, GadaBiyu are the most prospective for hydrocarbon exploratory drilling campaigns (Obaje et al., 2011; Usman, 2019) 
Petroleum forms by the breaking down of large molecules of fats, oils and waxes that contributed to the formation of kerogen (Mansoori et al., 2016) and it is mostly been recovered by oil drilling which is carried out after studies of structural geology (at the reservoir scale), sedimentary basin analysis, and reservoir characterization have been completed (Guerriero et al., 2012) and one of the methods used for hydrocarbon exploration, characterization and identification of microorganisms from hydrocarbon suspected site is commonly known as microbial prospecting and it is based on the fact that, gaseous hydrocarbons through effusion and diffusion migrate upward from subsurface petroleum accumulations, and are utilized by a variety of microorganisms present in the sub-soil ecosystem (Etiope, 2015; Hubert and Judd, 2020). The methane, ethane, propane, and butane-oxidizing bacteria exclusively use these gases as carbon source for their metabolic activities and growth. These microorganisms are mostly found enriched in the shallow soils and can differentiate between hydrocarbon prospective and non-prospective areas (Rasheed et al., 2014; Laso-Perez et al., 2019). With the increase in demand for petroleum products and diminishing indigenous production, it has become necessary to look out for probable potential zones with the aim of expanding the national exploration and production base and adding to the proven reserves. There is therefore the need for microbiological studies to prove that this Basin indeed can be explored for petroleum. Hence this study was directed to identify the presence of hydrocarbon gas oxidisers and anomalies as indicators to potent sites for exploration.

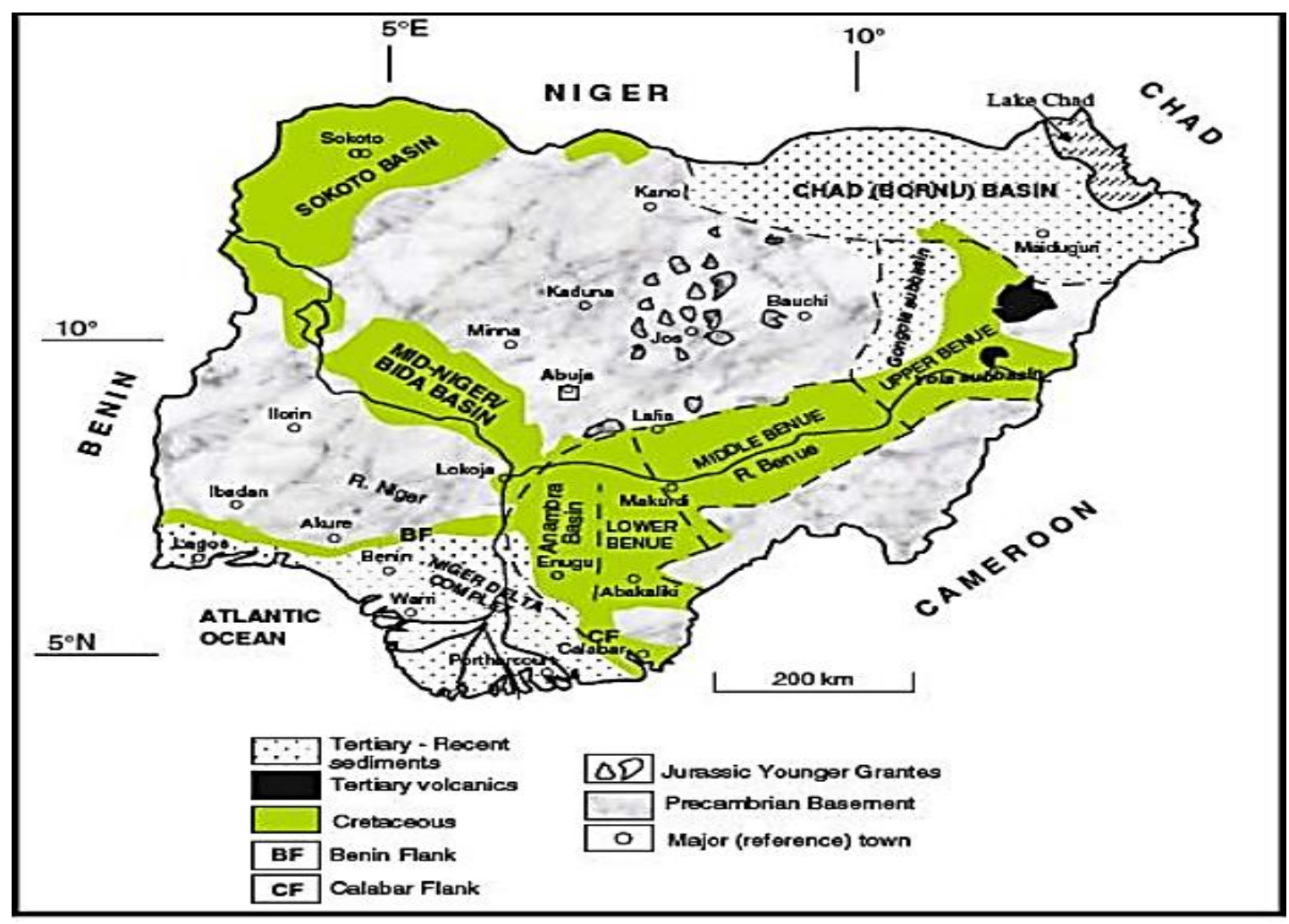

Figure 1: Geological map of Nigeria showing the position of Bida Basin (Obaje et al., 2011) 


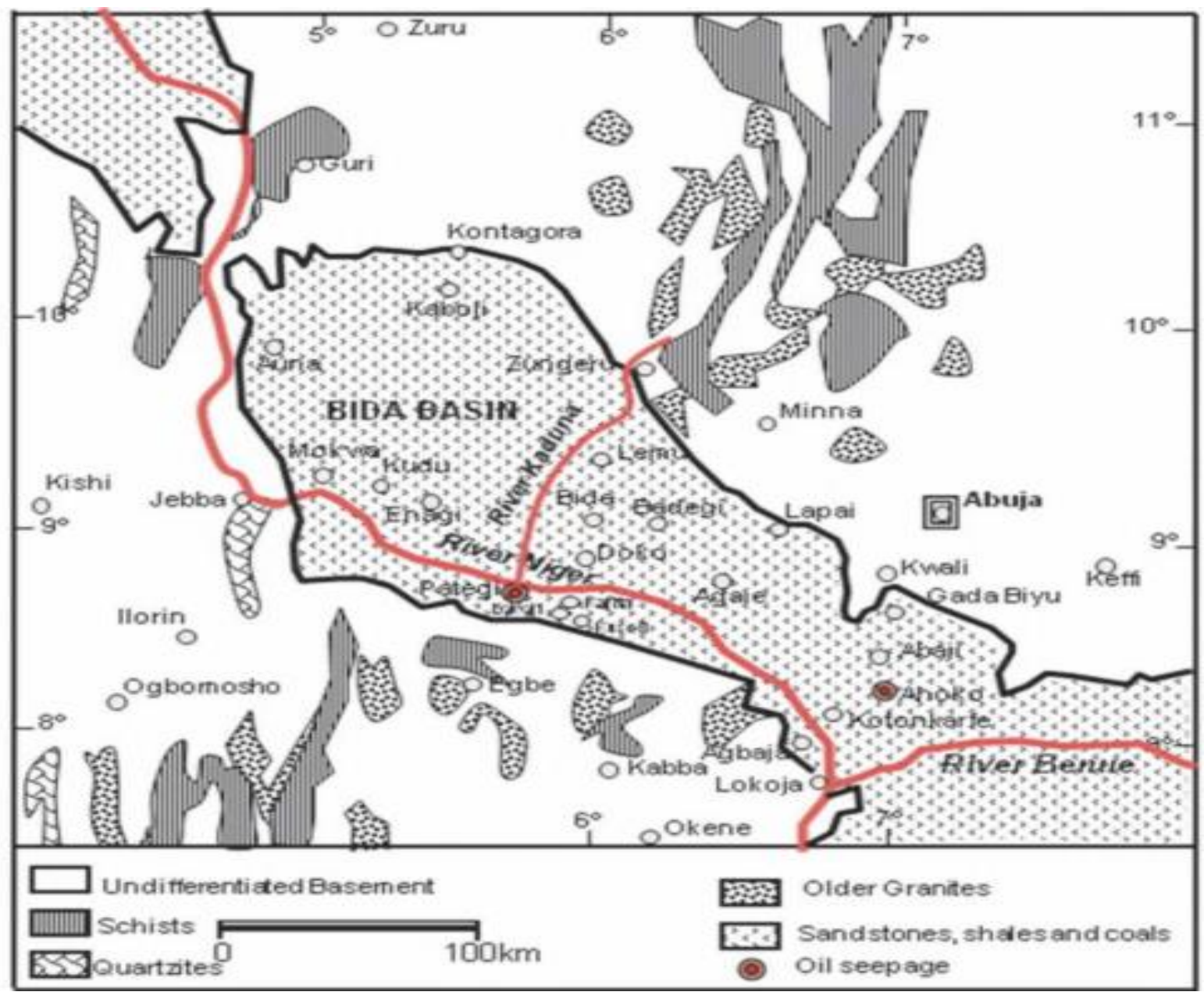

Figure 2: Geology

and Location of Bida Basin and its environs, showing Ahoko the study site (Obaje et al., 2011

\subsection{MATERIALS AND METHODS}

\subsection{Identification and Mapping of the Study Area}

The study area (Ahoko) is one of the four major areas (Ahoko, Petegi/Muregi, Enagi and Patitiabakolo) within the Bida basin.

Ahoko (Ebira, Gbagi and Idu) found along Abuja-Lokoja Express Way is a local government in lokoja, Kogi State, North central Nigeria. The area is characterized by two climatic seasons: dry season (November - March) and rainy season (April - October). The inhabitants of the area are predominantly Ebira, Gwagi and few Fulani whose major occupations are farming and Fishing. Its lies on longitude $8^{\circ} 00^{\prime \prime} \mathrm{N}$ and latitude $6^{\circ} 00^{\prime \prime} \mathrm{E}$ (Figure 3). 


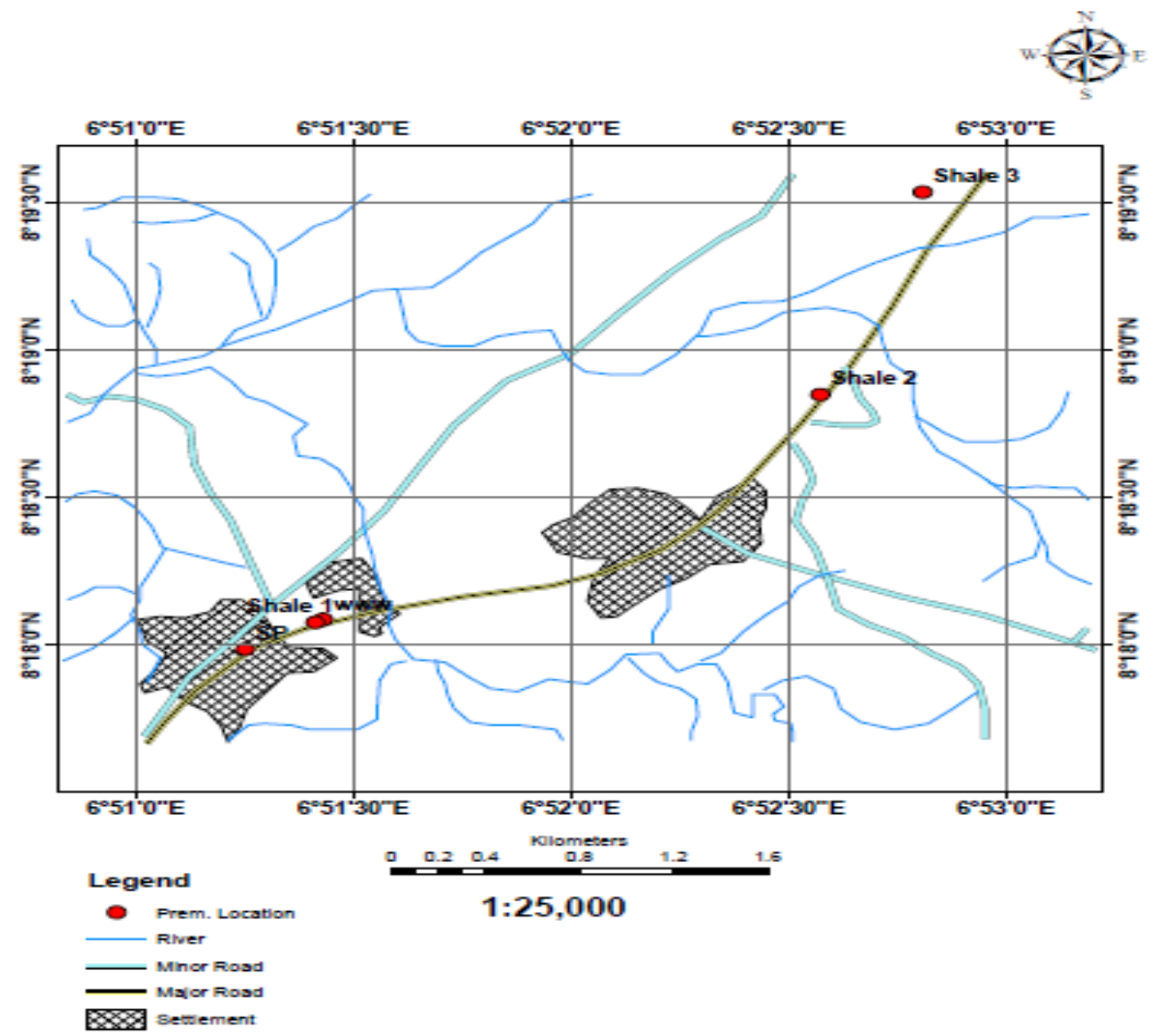

Figure 3: Map of study site showing points of sample collection

\subsection{Experimental Design and Sample Collection}

The identified sites were mapped and gridded $1 \mathrm{~km}$ by $1 \mathrm{~km}$ interval within an area of $4 \mathrm{~km}^{2}$. Samples were collected using soil core sampler by physical hammering into a depth of $1 \mathrm{~m}$. Each kilometre was partitioned into 5points and samples were collected in each point and were clustered into one sample. The samples were labelled along with their coordinates (Latitude and Longitude) ascertained using a Global Positioning System (GPS), thereafter it was transported to Microbiology Laboratory (Alex Ekwueme Federal University Ndufu Alike (AE-FUNAI) in an ice box where samples were analysed.

\subsection{Microbiological Analysis of the Soil samples}

\subsubsection{Enumeration of culturable heteroaerobic bacteria}


Freshly prepared Ringer's solution according to Anyanwu et al. (2016) was prepared and used to dislodge the microbial load in the sample. This was done by dissolving $10 \mathrm{~g}$ of soil sample into $90 \mathrm{ml}$ of the Ringer's solution; the mixtures were shaken for 5 minutes using magnetic stirrer at $30^{\circ} \mathrm{C}$. It was allowed to stand for 30 miuntes, then one millilitre of the stock was taken into $9 \mathrm{ml}$ of the ringer's solution dispensed into test tubes and then serial dilutions were made to obtain the dilution of $10^{-1}$ to $10^{-10}, 0.05 \mathrm{ml}$ of the diluents of $10^{-4}$ to $10^{-10}$ was inoculated into $18 \mathrm{ml}$ each of freshly prepared sterile molten Nutrient Agar, the mixture was transferred by pour plate method into sterile Petri dishes which were swirled and allowed to cool at ambient temperature $\left(26^{\circ} \mathrm{C} \pm\right.$ $2^{\circ} \mathrm{C}$ ) for 30 minutes on a flat surface. The inoculated culture plates were incubated at $37^{\circ} \mathrm{C}$ for 18 hours; after which the colonies that developed were counted using a colony counter. The results were recorded as colony forming units per gram (CFU/g) of soil.

\subsubsection{Enumeration of total fungi}

Total fungi count was carried out on Sabourand Dextrose Agar (SDA) (Hi-Media) supplemented with $10 \mathrm{mg} / \mathrm{l}$ of streptomycin. Triplicate plates were prepared, inoculated and incubated at $28^{\circ} \mathrm{C}$ for 72 hours. The colonies that developed were counted and recorded, and then it was allowed to grow for two more days to examine if other growth will occur. This was done for all the samples across the months sampled (February 2017-January 2018). The colony counts were expressed as colony forming units per gram of soil (CFU/g)

\subsection{Isolation of specific hydrocarbon utilizers (The check organisms for oil prospecting)}

Specific isolation of microbes associated with hydrocarbon seepage was done using Light carbon gas of $\mathrm{C}_{1}-\mathrm{C} 4$ (methane, ethane, propane, butane). Isolation and enumeration of microorganisms for each sample was carried out by Standard Plate Count (SPC) method as used by Rasheed et al. (2015).

Serially diluted soil suspension was inoculated into sterile molten Mineral Salts Medium (MSM) containing $1.0 \mathrm{~g} \mathrm{MgSO}_{4} .7 \mathrm{H}_{2} 0$, $0.7 \mathrm{~g} \mathrm{~K}_{2} \mathrm{HPO}_{4}, 0.54 \mathrm{~g} \mathrm{KH}_{2} \mathrm{PO}_{4}, 0.5 \mathrm{~g} \mathrm{NH}_{4} \mathrm{Cl}, 0.2 \mathrm{~g}$ of $\mathrm{CaCl}_{2} .2 \mathrm{H}_{2} \mathrm{O}, 4.0 \mathrm{mg}$ of $\mathrm{FeSO}_{4} .7 \mathrm{H}_{2} \mathrm{O}, 0.3 \mathrm{mg}$ of $\mathrm{H}_{3} \mathrm{BO}$, $0.2 \mathrm{mg}$ of $\mathrm{CoCl}_{2} \cdot 6 \mathrm{H}_{2} \mathrm{O}, 0.1 \mathrm{mg}$ of $\mathrm{ZnSO}_{4} \cdot 7 \mathrm{H}_{2} \mathrm{O}, 0.06 \mathrm{mg} \mathrm{Na} \mathrm{MoO}_{4} \cdot 2 \mathrm{H}_{2} \mathrm{O}, 0.03 \mathrm{mg} \mathrm{MnCl}_{2} \cdot 4 \mathrm{H}_{2} \mathrm{O}, 0.02 \mathrm{mg}$ of $\mathrm{NiCl}_{2} \cdot 6 \mathrm{H}_{2} \mathrm{O}$, and $0.01 \mathrm{mg}$ of $\mathrm{CuCl}_{2} \cdot 2 \mathrm{H}_{2} \mathrm{O}$ in $1000 \mathrm{~mL}$ of distilled water, at $\mathrm{pH}$ 7.0. The plates were placed in a desiccator, loaded with potassium hydroxide pellet at the bottom and closed with greased lid and paraffin. Then it was connected to vacuum pump for 5 minutes to remove air, after vacuum was created, the loaded desiccator was filled with the desired hydrocarbon gas (methane/ethane/propane with 99.99 $\%$ purity). The desiccators were then kept in incubators at $35 \pm 2{ }^{\circ} \mathrm{C}$ for 10 days. After incubation, the colonies of methane, ethane, propane and butane oxidizing bacteria was manually counted and reported in colony forming units per gram (CFU/g) of soil sample.

\subsection{Physicochemical Analysis of Soil}

www.scirj.org

(C) 2020, Scientific Research Journal

http://dx.doi.org/10.31364/SCIRJ/v8.i5.2020.P0520772

This publication is licensed under Creative Commons Attribution CC BY. 
The Physical and Chemical properties of soil samples collected from the study areas were analysed using methods according to the Association of Official Analytical Chemists (AOAC, 1990).

\subsection{Distribution of Hydrocarbon Oxidizing Microorganisms (HOM)}

The distribution of hydrocarbon oxidizing microbes was achieved from distribution maps that were prepared with Geographical Information System (GIS) to delineate the potential areas with high yields (Veena Prasanna et al., 2013). The concentration distribution maps of methane, ethane, propane and butane oxidizing microbes enumerated from the soil samples was plotted on geological map of the study area. The higher populations of these hydrocarbon oxidizing microbes was observed and used to delineate the hydrocarbon potential zones

\subsection{RESULTS}

\subsection{Physicochemical properties of Ahoko soil}

The phsiochemical propersities of the soil as shown in Figure 4 revealed the $\mathrm{pH}$ values to be between 5.30-5.58, 5.95-6.79, 6.727.05 and 6.15-6.81 for Site A, B, C and D respectively, which indicates the soil are slightly acidic with conductivity and pore space values of $12 \mu \mathrm{f} / \mathrm{cm}(160 \%), 2.60 \mu \mathrm{f} / \mathrm{cm}(174 \%), 4.10 \mu \mathrm{f} / \mathrm{cm}(178 \%)$ and $3.30 \mu \int / \mathrm{cm}(192 \%)$ respectively (Figure $\left.4 \mathrm{a}-4 \mathrm{~d}\right)$.

\subsection{Microbiological Qualities of the Soil}

\subsubsection{Total aerobic heterotrophic bacteria in soil}

The counts of bacteria in the soil from Ahoko study area varied with respect to the months of sampling, the counts ranged from $1.17 \times 10^{6} \mathrm{CFU} / \mathrm{g}$ (March) to $2.67 \times 10^{6} \mathrm{cfu} / \mathrm{g}$ in April for site A, $0.95 \times 10^{6} \mathrm{CFU} / \mathrm{g}$ in August to $2.88 \times 10^{6} \mathrm{CFU} / \mathrm{g}$ (April) for site B, $0.55 \times 10^{6} \mathrm{CFU} / \mathrm{g}$ in August, $2.8 \times 10^{6} \mathrm{CFU} / \mathrm{g}$ in May for site $\mathrm{C}$ and $0.38 \times 10^{6} \mathrm{CFU} / \mathrm{g}$ in February to $2.02 \times 10^{6} \mathrm{CFU} / \mathrm{g}$ in October for site D (Table 1). It was observed that there was an increase in the number of bacterial count from April in all the sites (A-D) this maybe because it's a mouth of rainfall onset where the temperature of the soil changes to favour the growth of organisms.

The water current which is high during the rainy season may have been responsible in sweeping the bacterial away, although the decrease in number are not significant $(\mathrm{P}>0.05)$ which implies that the organisms may be indigenous in the soil. 


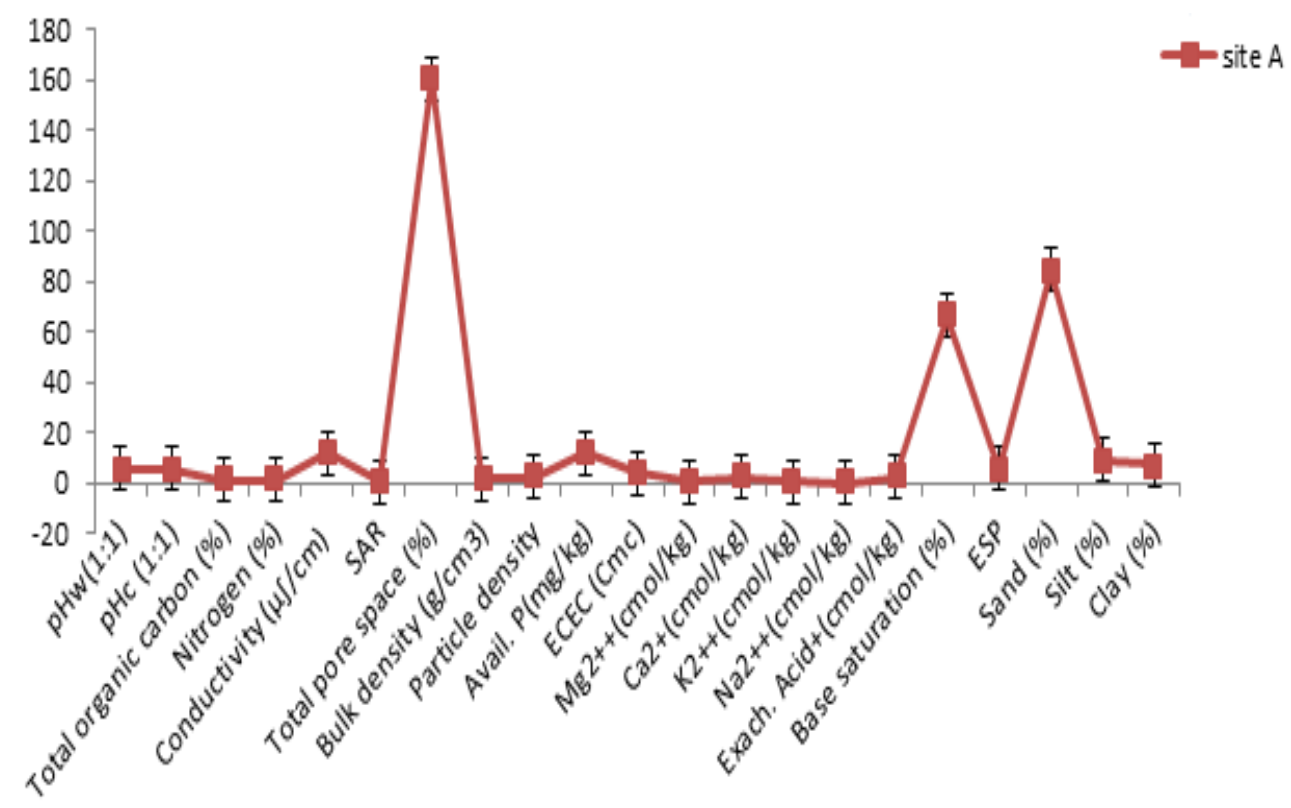

PARAMETERS

Figure 4a: Physicochemical properties of Ahoko soil, Site A

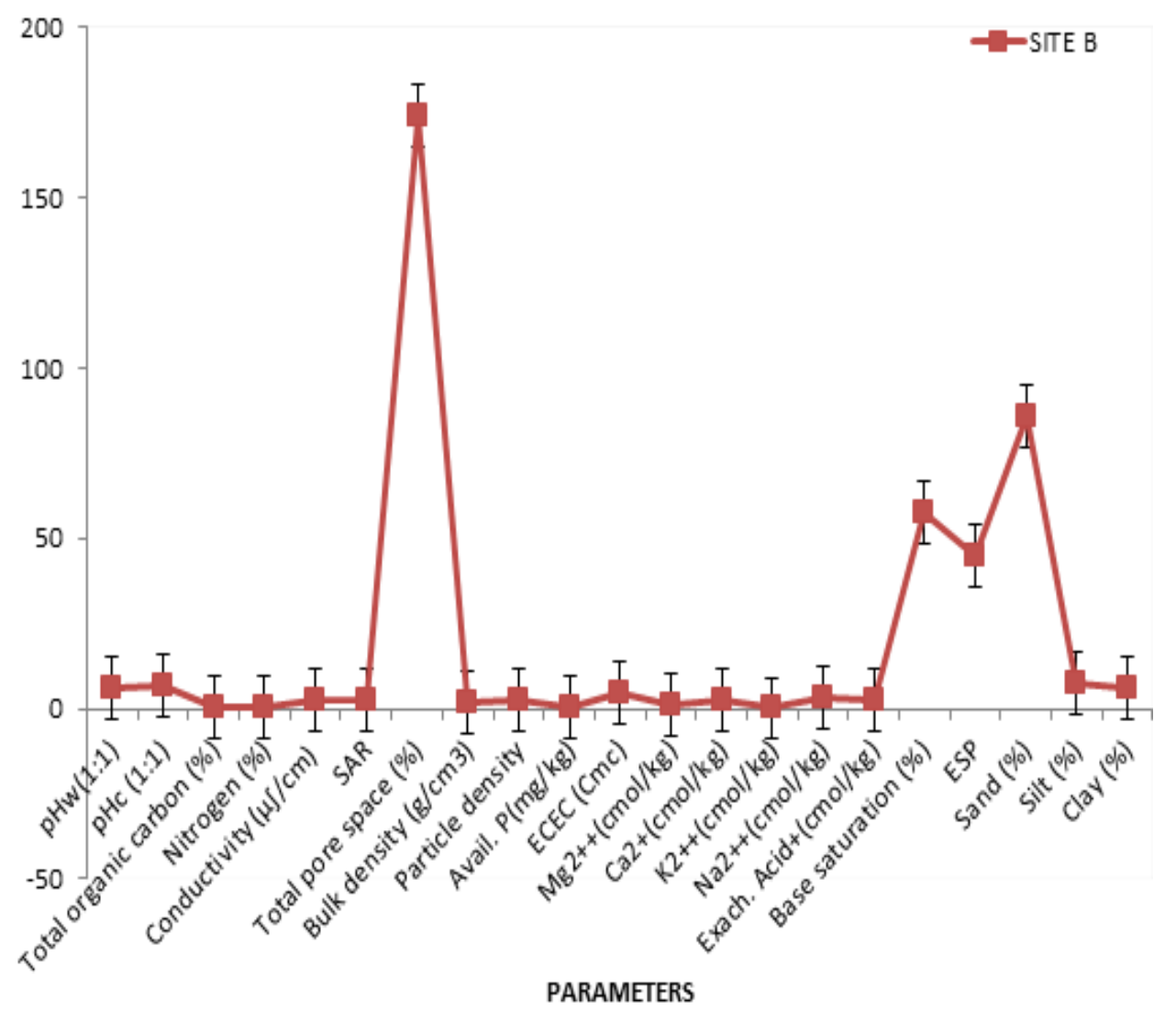

Figure 4b: Physicochemical properties of Ahoko soil, Site B 


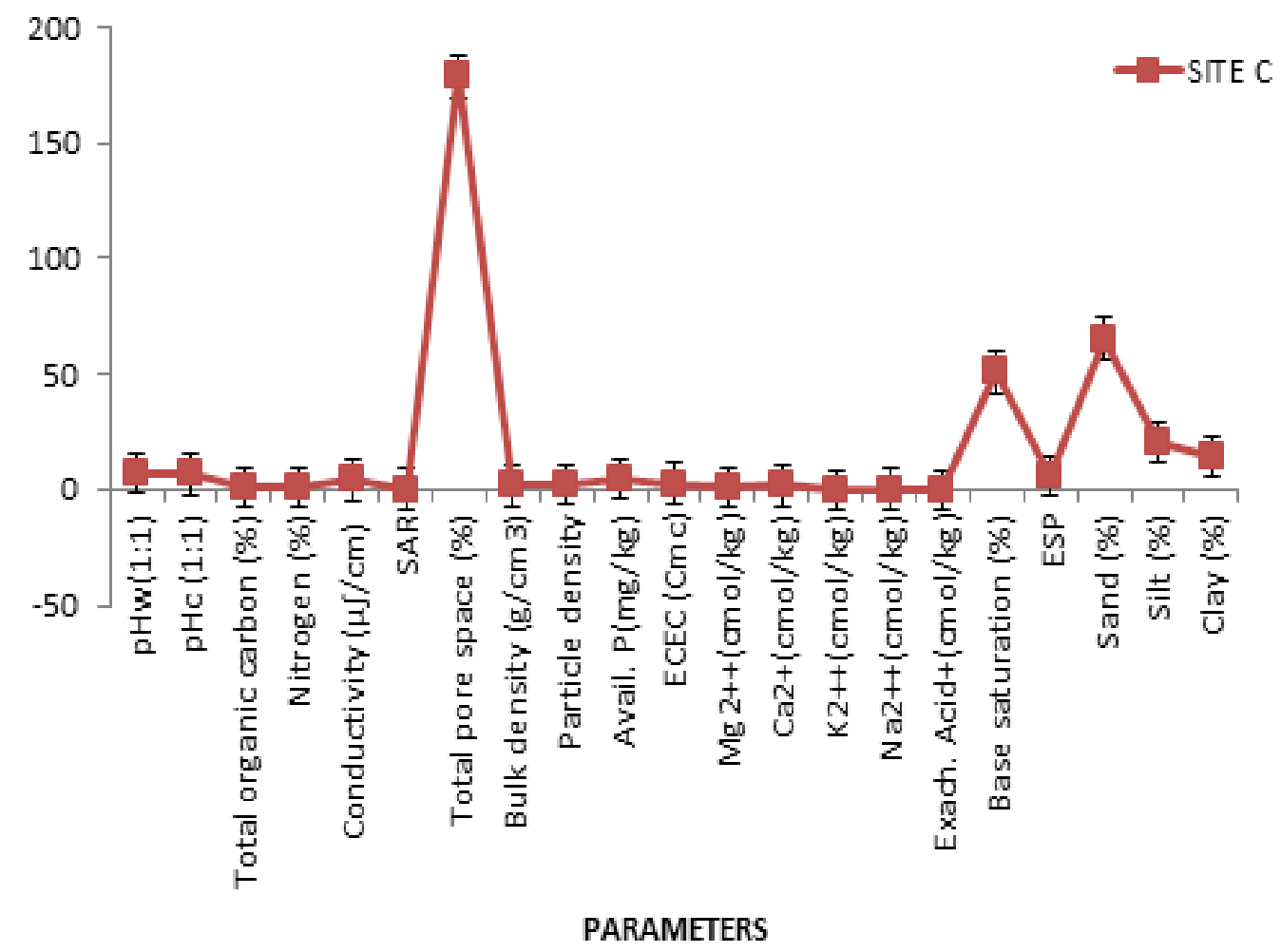

Figure 4c: Physicochemical properties of Ahoko soil, Site C

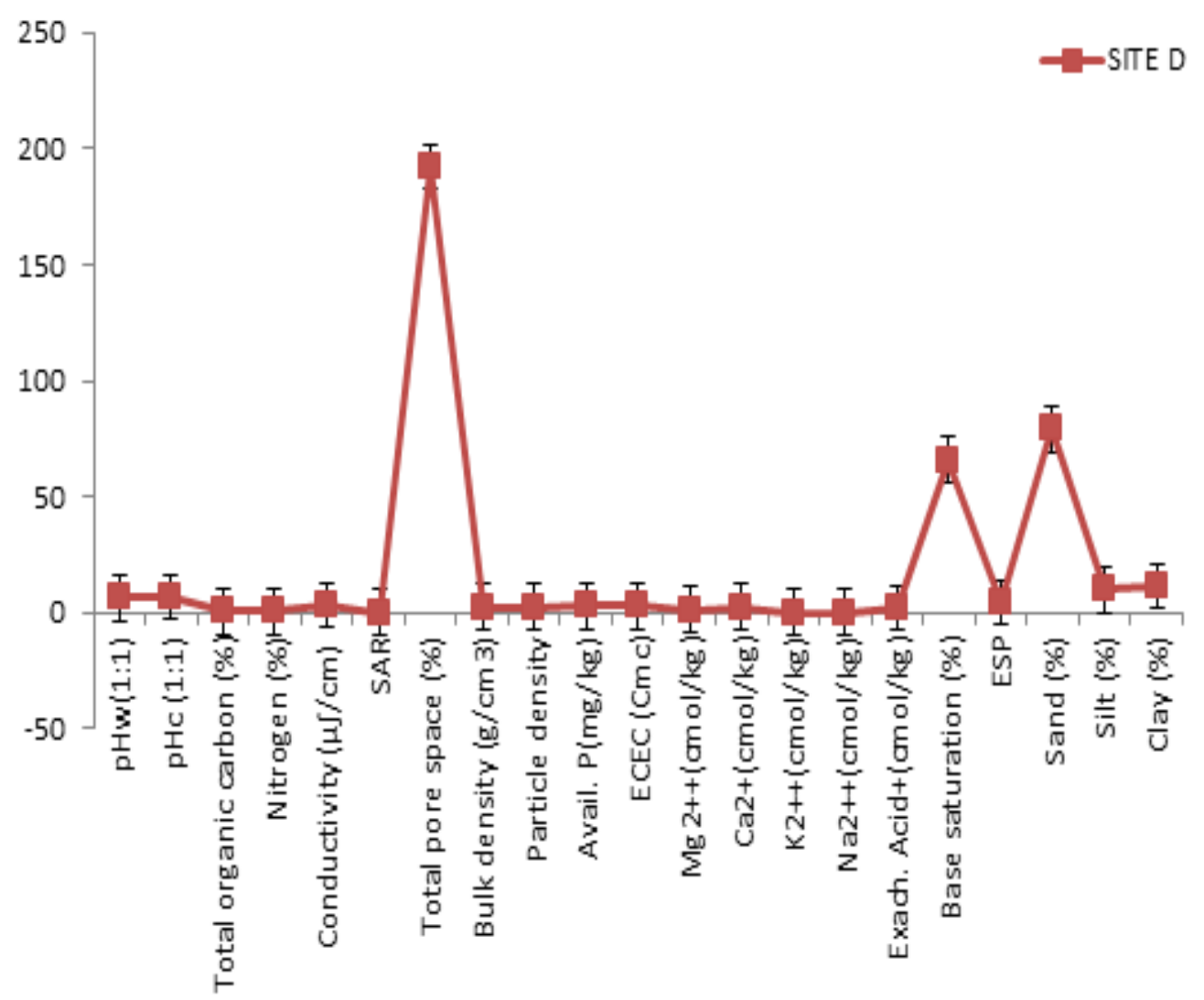

PARAMETERS

Figure 1d: Physicochemical properties of Ahoko soil, Site D 


\subsubsection{Enumeration of Total fungi in Soil}

The total number of culture-able fungi in the sampled soil ranged from $3.16 \times 10^{3} \mathrm{CFU} / \mathrm{g}$ to $6.60 \times 10^{3} \mathrm{CFU} / \mathrm{g} ; 1.27 \times 10^{3} \mathrm{CFU} / \mathrm{g}$ to $4.51 \times 10^{3} \mathrm{CFU} / \mathrm{g} ; 2.22 \times 10^{3} \mathrm{CFU} / \mathrm{g}$ to $11.0 \times 10^{3} \mathrm{CFU} / \mathrm{g} ; 2.27 \times 10^{3} \mathrm{CFU} / \mathrm{g}$ to $6.6 \times 10^{3} \mathrm{CFU} / \mathrm{g}$ for Site A, Site B, Site C and Site D respectively. It was observed that the counts were not consistent following the month and season of the year, December, January and February had the least count across the study site, while May, June and July had higher counts of the fungi (Table 2). More so, there was an increase in the number of Fungi from $3.05 \times 10^{3} \mathrm{CFU} / \mathrm{g}, 1.86 \times 10^{3} \mathrm{CFU} / \mathrm{g}, 3.71 \times 10^{3} \mathrm{CFU} / \mathrm{g}$ and $2.87 \times 10^{3} \mathrm{CFU} / \mathrm{g}$ (March) to $3.51 \times 10^{3} \mathrm{CFU} / \mathrm{g}$ 2.19X10 $\mathrm{CFU} / \mathrm{g} 4.35 \times 10^{3} \mathrm{CFU} / \mathrm{g}$ and $3.36 \times 10^{3} \mathrm{CFU} / \mathrm{g}$ (April) within the sites $\mathrm{A}$, B, C and D respectively this increase continued consistently till July and a slight decrease was observed in the month of August this maybe as a result in the break of rainfall popularly known as August break which lead to the decrease in the moisture content of the soil and thereby affect the growth of the fungi (Table 2).

Table 1: Bacterial $\left(\mathrm{CFU} / \mathrm{g} \times 10^{6}\right)$ count in Ahoko soil

\section{Samples}

\begin{tabular}{|c|c|c|c|c|}
\hline Months & Site A & Site B & Site C & Site D \\
\hline February & $1.4 \pm 0.3^{\mathrm{ab}}$ & $1.05 \pm 0.00^{\mathrm{a}}$ & $0.6 \pm 0.025^{\mathrm{a}}$ & $0.38 \pm 0.10^{\mathrm{a}}$ \\
\hline March & $1.17 \pm 0.05^{\mathrm{a}}$ & $0.99 \pm 0.03^{\mathrm{a}}$ & $0.57 \pm 0.029^{\mathrm{a}}$ & $0.67 \pm 0.11^{\mathrm{a}}$ \\
\hline April & $2.67 \pm 0.2^{\mathrm{e}}$ & $2.88 \pm 0.33^{\mathrm{e}}$ & $1.62 \pm 0.075^{\mathrm{ab}}$ & $1.44 \pm 0.2^{\mathrm{ab}}$ \\
\hline May & $1.71 \pm 0.25^{\mathrm{b}}$ & $0.97 \pm 0.06^{\mathrm{a}}$ & $2.8 \pm 0.05^{\mathrm{e}}$ & $1.5 \pm 0.00^{\mathrm{b}}$ \\
\hline June & $1.75 \pm 0.38^{\mathrm{bc}}$ & $1.03 \pm 0.06^{\mathrm{a}}$ & $0.8 \pm 0.075^{\mathrm{a}}$ & $0.77 \pm 0.025^{\mathrm{a}}$ \\
\hline July & $1.18 \pm 0.28^{\mathrm{a}}$ & $1.0 \pm 0.05^{\mathrm{a}}$ & $0.58 \pm 0.1^{\mathrm{a}}$ & $0.95 \pm 0.05^{\mathrm{a}}$ \\
\hline August & $1.20 \pm 0.26^{\mathrm{a}}$ & $0.95 \pm 0.00^{\mathrm{a}}$ & $0.55 \pm 0.05^{\mathrm{a}}$ & $1.03 \pm 0.025^{\mathrm{a}}$ \\
\hline September & $1.63 \pm 0.15^{\mathrm{a}}$ & $1.0 \pm 0.05^{\mathrm{a}}$ & $1.09 \pm 0.00^{\mathrm{a}}$ & $1.5 \pm 0.1^{\mathrm{ab}}$ \\
\hline October & $2.53 \pm 0.1^{\mathrm{de}}$ & $2.27 \pm 0.24^{\mathrm{abcd}}$ & $1.63 \pm 0.3^{\mathrm{ab}}$ & $2.02 \pm 0.3^{\mathrm{bc}}$ \\
\hline November & $2.15 \pm 0.21^{\mathrm{cd}}$ & $2.05 \pm 0.1^{\mathrm{bcd}}$ & $1.90 \pm 0.02^{\mathrm{bc}}$ & $1.60 \pm 0.09^{\mathrm{ab}}$ \\
\hline
\end{tabular}




\begin{tabular}{|c|c|c|c|c|}
\hline December & $2.17 \pm 0.14^{\mathrm{cd}}$ & $1.52 \pm 0.06^{\mathrm{ab}}$ & $1.42 \pm 0.07^{\mathrm{ab}}$ & $1.52 \pm 0.1^{\mathrm{b}}$ \\
\hline January 2018 & $1.75 \pm 0.05^{\mathrm{b}}$ & $1.32 \pm 0.021^{\mathrm{a}}$ & $1.42 \pm 0.07^{\mathrm{ab}}$ & $1.20 \pm 0.19^{\mathrm{a}}$ \\
\hline
\end{tabular}

Values are mean \pm standard error of mean of triplicate determinations. Values with different alphabets are significantly different $(\mathrm{p}<0.05)$ between means along the column.

Table 2: Total fungi count $\left(10^{3} \mathrm{CFU} / \mathrm{g}\right)$ in Ahoko soil

\section{Sample}

$\begin{array}{llll}\text { Site A } & \text { Site B } & \text { Site C }\end{array}$

Months

\begin{tabular}{|c|c|c|c|c|}
\hline February(2017) & $3.16 \pm 0.00^{\mathrm{b}}$ & $1.86 \pm 0.15^{\mathrm{a}}$ & $3.9 \pm 0.17^{\mathrm{bc}}$ & $2.98 \pm 0.7^{\mathrm{ab}}$ \\
\hline March & $3.05 \pm 0.01^{\mathrm{b}}$ & $1.86 \pm 0.00^{\mathrm{a}}$ & $3.71 \pm 0.2^{\mathrm{bc}}$ & $2.87 \pm 0.05^{\mathrm{ab}}$ \\
\hline April & $3.51 \pm 0.00^{\mathrm{bc}}$ & $2.19 \pm 0.1^{\mathrm{ab}}$ & $4.35 \pm 0.01^{\mathrm{c}}$ & $3.36 \pm 0.02^{b c}$ \\
\hline May & $6.6 \pm 0.1^{\mathrm{de}}$ & $2.34 \pm 0.06^{\mathrm{b}}$ & $11.0 \pm 4.72^{\text {defg }}$ & $6.4 \pm 0.01^{\mathrm{de}}$ \\
\hline June & $6.01 \pm 0.00^{\mathrm{d}}$ & $4.14 \pm 0.2^{c}$ & $9.8 \pm 5.0^{\mathrm{f}}$ & $6.6 \pm 0.70^{\mathrm{e}}$ \\
\hline July & $5.45 \pm 0.02^{\mathrm{cd}}$ & $4.51 \pm 0.06^{\mathrm{cd}}$ & $9.85 \pm 0.04^{\mathrm{fg}}$ & $6.6 \pm 0.70 \mathrm{de}$ \\
\hline August & $5.01 \pm 0.5^{\mathrm{bcd}}$ & $4.01 \pm 0.70^{\mathrm{c}}$ & $9.19 \pm 1.27^{\mathrm{f}}$ & $6.07 \pm 0.99^{\mathrm{e}}$ \\
\hline September & $5.4 \pm 0.02^{\mathrm{cd}}$ & $3.47 \pm 0.27^{\mathrm{abc}}$ & $9.05 \pm 2.2^{\mathrm{f}}$ & $5.97 \pm 0.15^{\mathrm{de}}$ \\
\hline October & $6.0 \pm 0.7^{\mathrm{abcd}}$ & $3.42 \pm 0.50^{\mathrm{ab}}$ & $9.05 \pm 1.0^{\mathrm{f}}$ & $6.16 \pm 0.1^{\mathrm{de}}$ \\
\hline November & $5.4 \pm 0.33^{\mathrm{cd}}$ & $3.0 \pm 0.70^{\mathrm{b}}$ & $5.3 \pm 0.7^{\mathrm{d}}$ & $4.57 \pm 0.13^{\mathrm{abcd}}$ \\
\hline December & $4.71 \pm 0.06^{\mathrm{d}}$ & $2.5 \pm 0.03^{\mathrm{b}}$ & $3.65 \pm 0.33^{\mathrm{c}}$ & $3.5 \pm 0.25^{\mathrm{c}}$ \\
\hline January(2018) & $3.17 \pm 0.25^{\mathrm{b}}$ & $1.27 \pm 0.33^{\mathrm{a}}$ & $2.22 \pm 0.25^{\mathrm{ab}}$ & $2.27 \pm 0.25^{\mathrm{ab}}$ \\
\hline
\end{tabular}

Values are mean \pm standard error of mean of triplicate determinations. Values with different alphabets are significantly different $(\mathrm{p}<0.05)$ between means along the column

Values are mean of triplicate determinations.

\section{Isolation of specific hydrocarbon utilizers (The check organisms for oil prospecting)}


The result of methane oxidising microbes as shown in Figure 5 revealed that Site A had the highest number of count throughout the study period with no significant difference $(\mathrm{P}>0.05)$ in the months sampled (February to January). It was also observed that the count of MOM in site $\mathrm{C}$ consistently reduced from March $\left(0.1742 \times 10^{2} \mathrm{CFU} / \mathrm{g}\right)$ to October $\left(0.03 \times 10^{2} \mathrm{CFU} / \mathrm{g}\right)$ and $\mathrm{reminded}$ constant at $0.02 \times 10^{2} \mathrm{CFU} / \mathrm{g}$ from November to January (Figure 5)

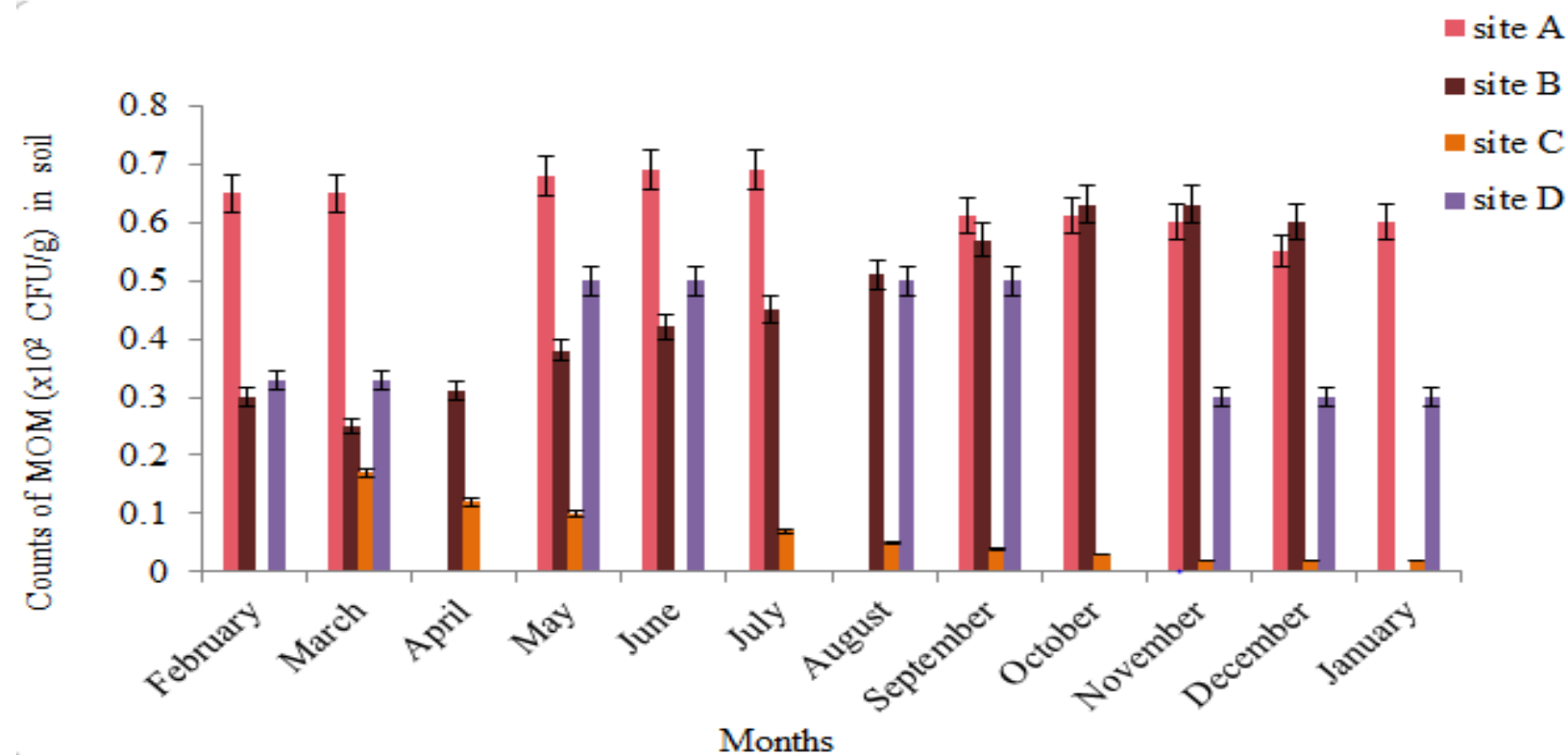

B C and D are alphabetical codes used to represent the points where samples were collected (referring to samples) Figure 5: Counts of methane oxidizing microbes (MOM) in soil

The result for the ethane oxidizing microbes ranges from $0.42 \times 10^{2} \mathrm{CFU} / \mathrm{g}$ to $1.33 \times 10^{2} \mathrm{CFU} / \mathrm{g}$ for Site $\mathrm{A}, 0.3 \times 10^{2} \mathrm{CFU} / \mathrm{g}$ to $0.92 \times 10^{2} \mathrm{CFU} / \mathrm{g}, 0.05 \times 10^{2} \mathrm{CFU} / \mathrm{g}$ to $0.67 \times 10^{2} \mathrm{CFU} / \mathrm{g}$, and 0.00 to $0.8 \times 10^{2} \mathrm{CFU} / \mathrm{g}$ for Site $\mathrm{B}$, C and D respectively (Figure 6 ). The result reveals that the seasonal change within the period of study affect the microbial growth. For site A, the highest growth or microbial count was observed in the month of February $\left(1.33 \times 10^{2} \mathrm{CFU} / \mathrm{g}\right)$, this is closely followed by $1.2 \times 10^{2} \mathrm{CFU} / \mathrm{g}$ in March, $1.07 \times 10^{2} \mathrm{CFU} / \mathrm{g}$ in November and $1.12 \times 10^{2} \mathrm{CFU} / \mathrm{g}$ in January (Figure 6). This implies that the growths were favoured during the dry season rather than wet season as observed in Site $\mathrm{C}$, this observation may be associated with the nature of the soil type 


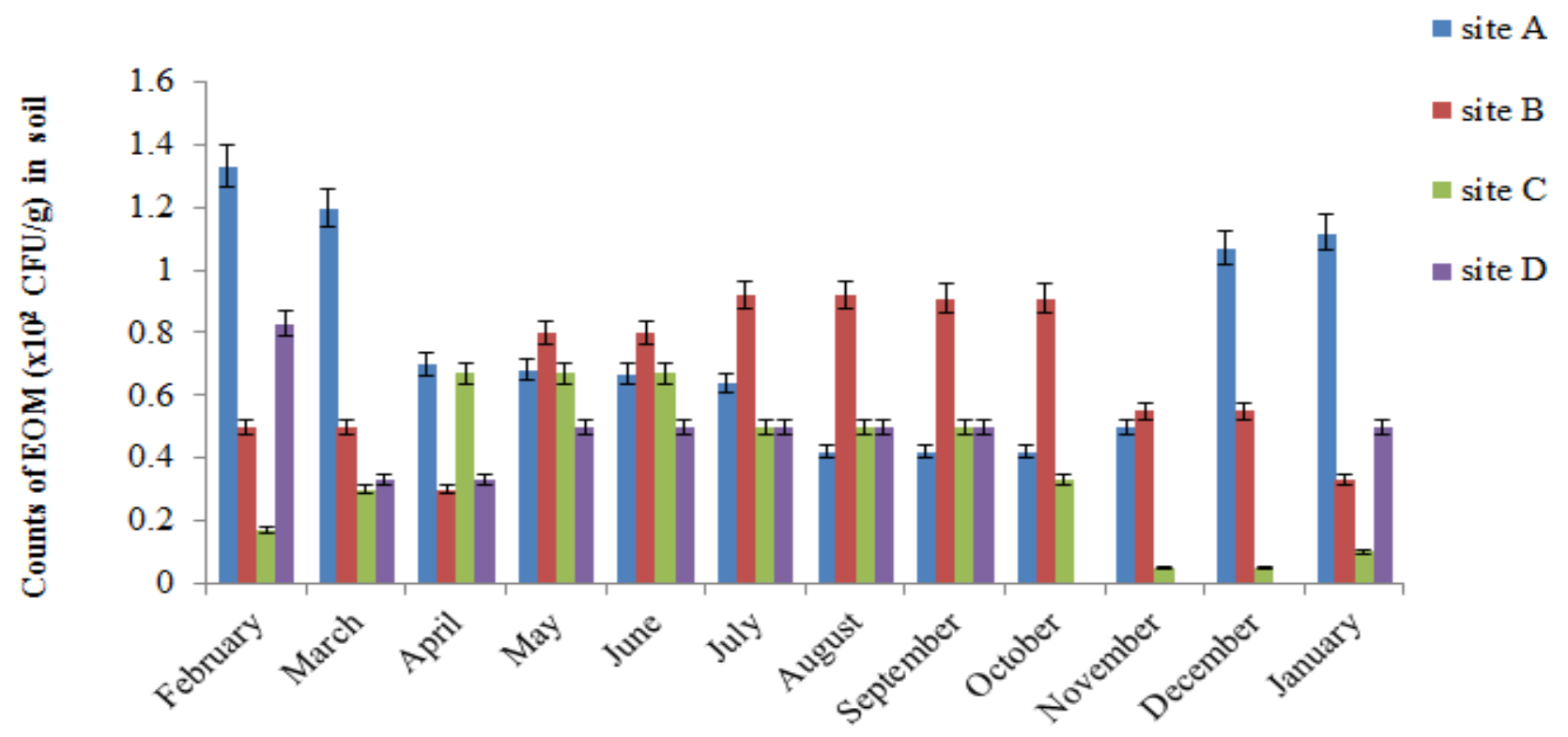

Months

Key: Site A,

B C and D are alphabetical codes used to represent the points where samples were collected (referring to samples) Figure 6: Counts of Ethane oxidizing microbes (EOM) in soil

The number of culture-able propane oxidizing microbe was carried out from February 2017 to January 2018. It was observed that there were variation in number with respect to month and seasons of the year (Figure 7).

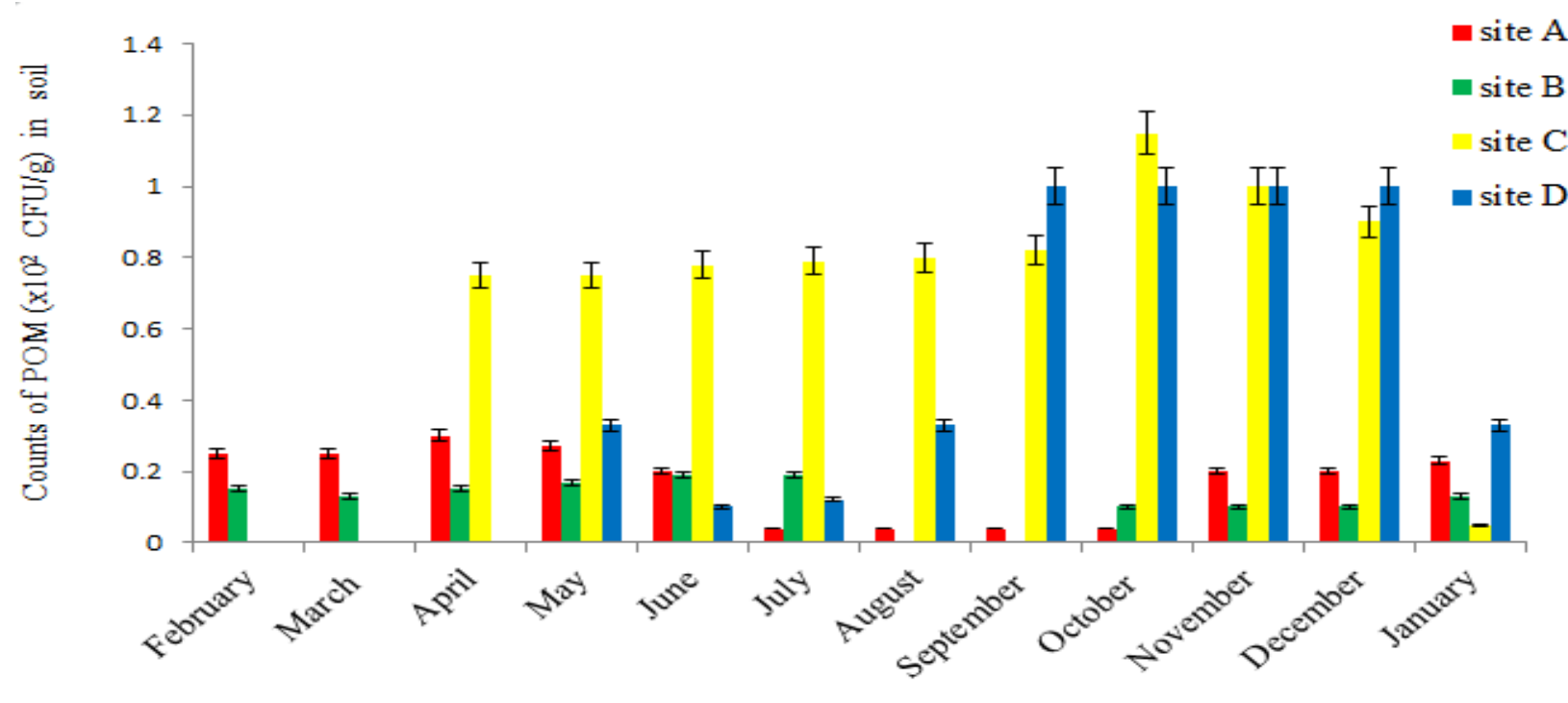

Months

Key: Site A,

B C and D are alphabetical codes used to represent the points where samples were collected (referring to samples)

Figure 7: Counts of Propane oxidizing microbes (POM) in soil

Table 3: Enumeration of Butane oxidizing microbes (BOM)@ $10^{2} \mathrm{CFU} / \mathrm{g}$

Samples
Months
Site A
Site B
Site C
Site D 


\begin{tabular}{lcccc}
\hline February & $0.15 \pm 0.00^{\mathrm{ab}}$ & $0.15 \pm 0.001^{\mathrm{ab}}$ & $\mathrm{NG}$ & $\mathrm{NG}$ \\
March & $0.1 \pm 0.001 \mathrm{a}$ & $0.13 \pm 0.002^{\mathrm{a}}$ & $\mathrm{NG}$ & $\mathrm{NG}$ \\
April & $\mathrm{NG}$ & $\mathrm{NG}$ & $\mathrm{NG}$ & $\mathrm{NG}$ \\
May & $\mathrm{NG}$ & $\mathrm{NG}$ & $\mathrm{NG}$ & $\mathrm{NG}$ \\
June & $\mathrm{NG}$ & $\mathrm{NG}$ & $\mathrm{NG}$ & $\mathrm{NG}$ \\
July & $\mathrm{NG}$ & $\mathrm{NG}$ & $\mathrm{NG}$ & $\mathrm{NG}$ \\
August & $0.04 \pm 0.00^{\mathrm{a}}$ & $\mathrm{NG}$ & $0.22 \pm 0.00^{\mathrm{a}}$ & $0.33 \pm 0.00^{\mathrm{b}}$ \\
September & $0.04 \pm 0.001^{\mathrm{a}}$ & $\mathrm{NG}$ & $0.32 \pm 0.00^{\mathrm{b}}$ & $0.1 \pm 0.00^{\mathrm{ab}}$ \\
October & $0.04 \pm 0.001 \mathrm{a}$ & $0.1 \pm 0.00^{\mathrm{ab}}$ & $\mathrm{NG}$ & $0.01 \pm 0.00^{\mathrm{a}}$ \\
November & $0.2 \pm 0.00^{\mathrm{b}}$ & $0.1 \pm 0.0011^{\mathrm{ab}}$ & $0.01 \pm 0.00^{\mathrm{a}}$ & $0.01 \pm 0.00^{\mathrm{a}}$ \\
December & $0.2 \pm 0.00^{\mathrm{b}}$ & $0.1 \pm 0.003^{\mathrm{ab}}$ & $0.15 \pm 0.01^{\mathrm{ab}}$ & $0.1 \pm 0.011^{\mathrm{a}}$ \\
January & $\mathrm{NG}$ & $\mathrm{NG}$ & $\mathrm{NG}$ & $\mathrm{NG}$
\end{tabular}

Key: NG=No growth. Values are mean of triplicate determinations \pm standard error of mean of triplicate determinations. Values with different alphabets are significantly different $(\mathrm{p}<0.05)$ between means along the column

The higher populations of these hydrocarbon oxidizing microbes were observed in Site A area as revealed by the concentration distribution maps of methane, ethane, propane and butane oxidizing microbes (Figure 8).These were used to delineate the hydrocarbon potential zones. The high potential zone as delineated by the map is site A (SA) 

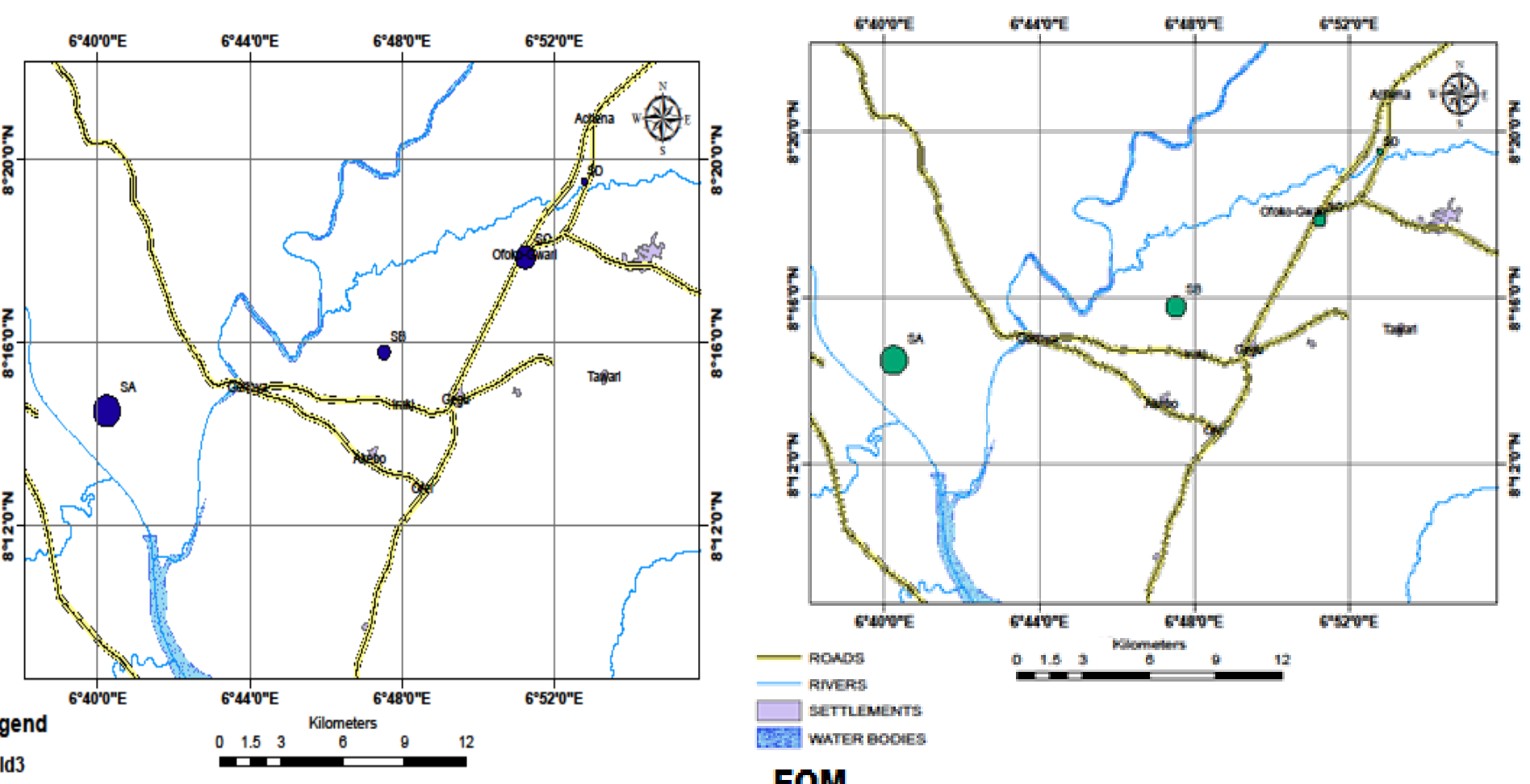

EOM
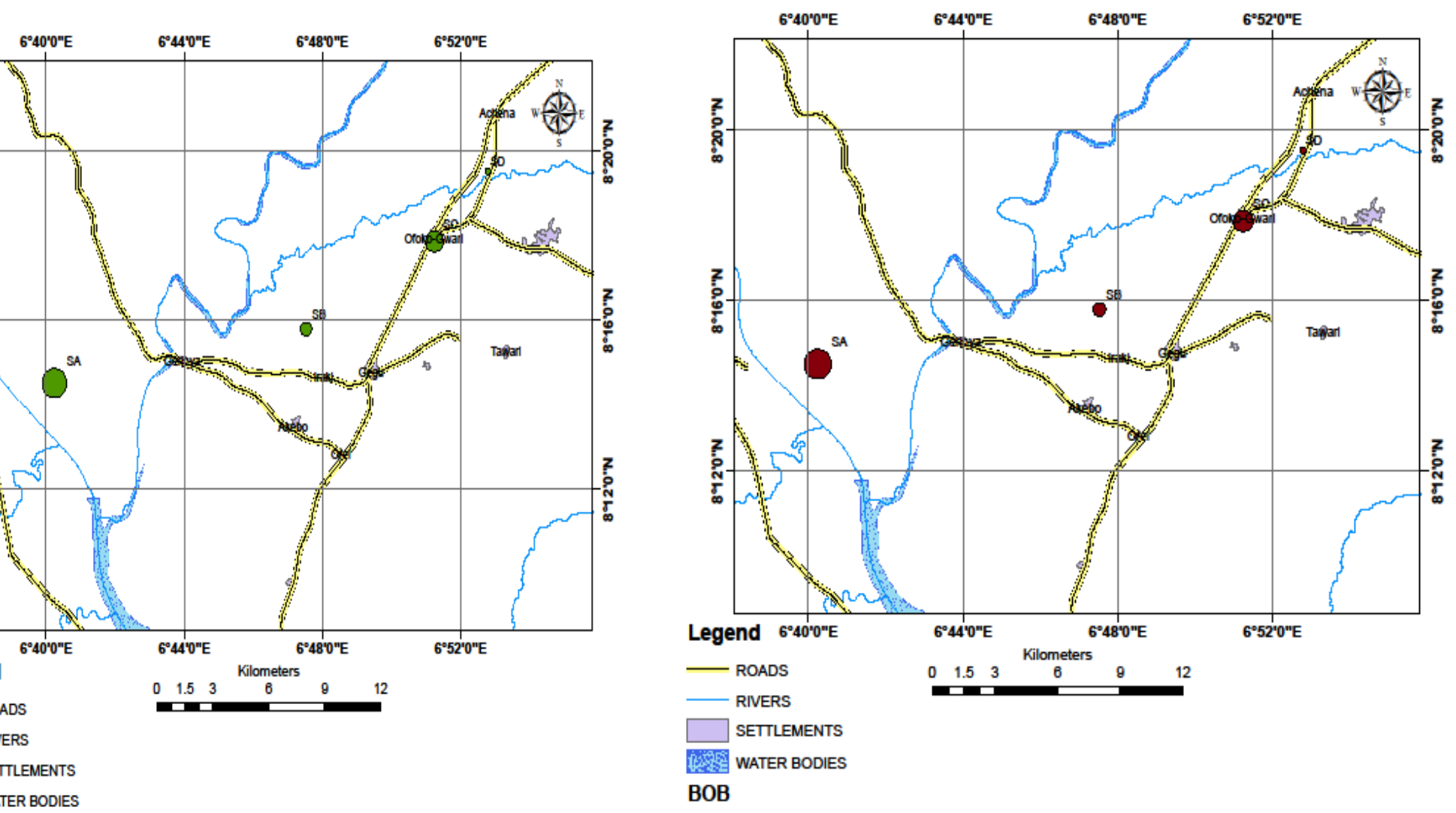

Figure 8: Concentration distribution maps of Methane, Ethane, Propane and Butane Oxidizing microbes

\section{DISCUSSION}


It was clear from the results that all sites harboured hydrocarbon oxidizing bacteria and fungi, although there was variations in counts, The mean total bacterial and fungal counts showed that more counts of TB were observed in the month of April and October (Table 1), while Total fungal (TF) were observed in the month of May, July and October than the months of December and February (Table 2) this will be connected to water content of the soil because in October the soil was wetter than December and February. This is in accordance to the work of Eze and Okpokwasili, (2010), Allamin et al. (2014); and Abioye et al.(2014) who stated that seasonal differences with higher microbial counts in wet than in dry season months may be attributed to increased water content of the soil. TB and TF abundance patterns were similar in all the sites A to D with differences in counts; the difference in count of the sites could be due to the difference in sites receiving domestic effluents, grazing activity and agricultural runoff which is similar to the findings of Eze and Okpokwasili, (2010), Allamin et al.(2014); and Abioye et al.(2014); who reported that variation in counts may be due to the industrial and domestic discharges to the sites.

It was observed that BOM has it least count of $1.0 \times 10^{3} \mathrm{CFU} / \mathrm{g}$ in the month of April (Table 3) while MOM, EOM and POM have their least count of $3.0 \times 10^{3}, 2.0 \times 10^{3}$ and 2.0x $10^{3} \mathrm{CFU} / \mathrm{g}$ respectively, in the mouth of March (Figure 5-7). This could be that the onset of the rain in April created a sudden shock on the organisms and this retarded their growth rate and affected their number. MOM recorded its highest count $\left(4.8 \times 10^{2}\right)$ in the month of April, EOM has its highest count $\left(4.6 \times 10^{2}\right)$ in April and December, and POM has its peak count in November, while BOM recorded a peak count of 3.0x10 $\mathrm{CFU} / \mathrm{g}$ in October. This implies that the numbers of these organisms are influenced by the seasons of the year which is tied to the temperature (Table 1-3). This is in agreement with Clark et al. (2000); Margesin et al. (2003); Head et al. (2006); Hamamura et al. (2006) and Kinnaman et al. (2010) whom reported a count of $2 \times 10^{10}$ gyear $^{-1}$ (methane), $1.9 \times 10^{9} \mathrm{CFU} / \mathrm{g}$ (ethane), and $1.4 \times 10^{9}$ (propane) from an established oil point seep field off shore of Santa Barbara, reported that the variations due to high dynamic environments is as a result of variable gas influx levels and seasonal changes in deposition.

The result for the ethane oxidizing microbes ranges from $0.42 \times 10^{2}$ to $1.33 \times 10^{2}$ for Site $\mathrm{A}, 0.3 \times 10^{2}$ to $0.92 \times 10^{2}, 0.05 \times 10^{2}$ to 0.67 $\mathrm{x} 10^{2}$, and 0.00 to $0.8 \times 10^{2} \mathrm{CFU} / \mathrm{g}$ for Site B, C and D respectively (Figure 6). The result reveals that the seasonal change within the period of study affect the microbial growth. For site A, the highest growth or microbial count was observed in the month of February $\left(1.33 \times 10^{2}\right)$, this is closely followed by $1.2 \times 10^{2}$ in March, $1.07 \times 10^{2}$ in November and $1.12 \times 10^{2}$ in January (Figure 6). This implies that the growths were favoured during the dry season rather than wet season as observed in Site C; this observation may be associated with the nature of the soil type, variable gas influx levels and seasonal changes in deposition (Head et al., 2006; Hamamura et al., 2006 and Kinnaman et al., 2010).

The presence of MOM is a sparing pointer to a potent site, but the high relative abundance and wide distribution of EOM (which are oxidizers of ethane gas $\mathrm{C}_{2}$ ) and POM (oxidizers of propane gas $\mathrm{C}_{3}$ ) especially in site A confirms the potency of this sites for oil exploration (Shennan, 2006; Kotani et al., 2006), however, the production may not be in large commercial quantity because the total counts were less than 10000ppm as affirmed by Rasheed et al.(2018). 


\section{CONCLUSION}

This study attempts to explore the oil and gas prospects of the Bida Basin using the surface geochemical prospecting methods.

Microbiological, and total organic and inorganic (physiocochemical properties) studies was applied to evaluate its hydrocarbon prospects. The microbial results indicate the presence of high bacterial anomalies for methane, ethane, and propane, and butane oxidizers near Akoko site indicating the area is prospective for hydrocarbons. The presence of propane and butane oxidising microbes is an indication that site $\mathrm{A}$ is a more potent site for oil exploration, although the quantity of oil may not be large to a commercial quantity because the number of organism were less than 1000ppm.

\section{REFERENCES}

Abdullahi, N. (2016). Bida Basin petroleum deposit. Retrieved from petroleum-deposit

www.kinnupeblog.com/bida basin-

Allamin, I. A., Ijah, U.J.J., Ismail, H.Y., \& Isa, M. A. (2014). Distribution of hydrocarbon degrading fungi in soil in Kukawa, Borno State, Nigeria. Merit Research Journal of Environmental Science and Toxicology, 2(7), 135-140

Association of Official Analytical chemists AOAC. (1990). Official methods of Analysis. Helrich K. (Ed.). $15^{\text {th }}$ ed. Association of Analytical chemists, Inc., USA, p.772

Clark, J., Washburn, L., Hornafius, J., and Luyendyk, B. (2000). Dissolved hydrocarbon flux from natural marine seeps to the southern California Bight. Journal of Geophysical Research and Oceans, 105,11509-11522.

Etiope, G. (2015). Natural gas seepage- The earths hydrocarbon degassing. Springer, Switerland. Pp199. Doi. 10.1007/978-

$3=319-14601.0$.

Hubert C. and Judd, A. (2020). Using microorganisms as prospecting agents in oil and gas exploration.in Timmis K.N. (eds). Handbook of hydrocarbon and Lipid Microbiology. Springer Berlin Heidelberg. https://doi.org/10.1007/973-3-540775877

Fawole, M. O. \& Oso, B. A.(1988). Laboratory Manual of Microbiology, Spectrum Books Limited. Ibadan, pp 22-33.

Guerriero, V., Mazzoli, S., Iannace, A. Vitale, S., Carravetta, A. \& Strauss, C. (2012). "A permeability model for naturally fractured carbonate reservoirs". Marine and Petroleum Geology, 40, 115-134, doi:10.1016/j.marpetgeo.2012.11.002

Ijah, U. J. J. \& Ukpe, L. I. (1992). Biodegradation of crude oil by Bacillus Strians 28A and 61B isolated from oil spilled soil. Waste Management, 12 (1), 55-60.

Kinnaman, F., Kimball, J. Busso, L. Birgel, D. Ding, H. Hinrichs, K. and Valentine, D.(2010). Gas flux and carbonate occurrence at a shallow seep of thermogenic natural gas. Geo-Marine Letters. 30:355-365.

Ladipo, k. (1988). paleogeography, sedimentary and tectonics of the upper cretaceous anambra Basin, south-eastern Nigeria. Journal of African Earth Science. 7, 865-871. 
Laso-Perez, R., Halm, C., Daan, M., Van, V., Halima, E.T. Flourence S., Nadine, T. S., Thomas P., Heikoa, S., Gerhard B., Boetius A., Katrin K., and Wegener G. (2019). Anaerobic degradation of non-methane alkanes by Candidatus methanoliparia in hydrocarbon seeps of the gulf of Mexico. MBIO 10 (4). Doi: 10:1128/mbio.01814-19.

Mansoori, G.A., Enayati, N., Agyarko L.B.(2016), Energy: Sources, Utilization, Legislation, Sustainability, Illinois as Model State. Energy, 1-37, doi: 10.1142/9789814704014_0001Margesin, R., Labbe, D., Schinner, F., Greer, C., \& Whyte, L. (2003). Characterization of hydrocarbon degrading microbial populations in contaminated and pristine alpine soils. Applied Environmental Microbiology, 69(6), 3085-3092.

Obaje, N. G., Musa, M. K., Odoma, A. N. \& Hamza. H. (2011). The Bida Basin in North-central Nigeria: sedimentology and petroleum geology. Journal of Petroleum and Gas Exploration Research, 1(1), 001-013.

Obaje, N. G., Musa, M. K., Odoma, A. N. and Hamza. H. (2011). The Bida Basin in north-central Nigeria: sedimentology and petroleum geology. Journal of Petroleum and Gas Exploration Research, 1(1), 1-13.

Rasheed M.A., Lakshmi, M., and Dayal, A. M. (2011). Bacteria as indicators for finding oil and gas reservoirs:A Case Study of Bikaner-Nagaur Basin, Rajasthan, India. Petroleum Science Journal., 8(3), 262-268.

Rasheed, M . A., Patil, D. J. and Dayal, A. M. (2013). Microbial Techniques for Hydrocarbon Exploration. India: 196-210. doi.org/10.5772/50885.

Rasheed, M . A., Patil, D. J. and Dayal, A. M. (2014). Microbial Techniques for Hydrocarbon Exploration. India, 196-210, doi.org/10.5772/50885

Rasheed, M. A., Hasan, S. Z., Rao, P. L., Boruah, P., Sudarshan, V., Kumar, B., \& Harinarayana, T. (2015). Application of geomicrobial prospecting method for finding oil and gas reservoirs. Frontier Earth Science, 9(1), 40-50.

Rasheed, M. A., McKenna, S. A., Taylor, H. A.,\& Sankey, T. L. (2008a). Long-term seagrass monitoring in Port Curtis and Rodds bay, Gladstone - November 2007. Department of Primary Industries Information Series PR07-3271, p. 32.

Rasheed, M. A., Prasanna, M.V., Kumar, T. S., Patil, D. J.,\& Dayal, A.M. (2008b). Geo-microbial prospecting method for hydrocarbon exploration in Vengannapalli Village, Cuddapah Basin, India. Current Science, 95,361-366

Rasheed, M. A.,Veena Prasanna, M., Lakshmi, M., Madhavi, T., Kalpana, M. S.,Patil, D. J., \& Dayal, A. M. (2012). Geomicrobial prospecting studies of surface sediments from petroliferous region of the Mehsana Block, North Cambay Basin. Journal of the Geological Society of India, 80, 267-271, doi:10.1007/s12594-012-0137-5

Rasheed, M.A., Lakshmi, M.,\& Dayal, A. M. (2011). Bacteria as indicators for finding oil and gas reservoirs:A Case Study of Bikaner-Nagaur Basin, Rajasthan, India. Petroleum Science Journal, 8(3), 262-268.

Shennan, J.L. (2006). Utilisation of C2-C4 gaseous hydrocarbons and isoprene by microorganisms. Journal of Chemical Technology and Biotechnology, 81, 237-256, doi: 10.1002/jctb.1388.

Veena Prasanna, M., Rasheed, M. A., Patil, D. J., Dayal, A. M., \& Rajeswara R. B. (2013). Geo-microbiological studies in conjunction with different geo-scientific studies for the evaluation of hydrocarbon prospects in Proterozoic Vindhyan Basin, India. Journal of Petroleum Science and Engineering, 108, 239-249. 